\title{
Growth and Development of Bitter Leaf (Vernonia amygdalina Del.) in Soils Treated with Mixture of Cadmium and Lead
}

\author{
*EDEGBAI, BO; ANOLIEFO, GO
}

\author{
Department of Plant Biology and Biotechnology, University of Benin, Benin City Nigeria \\ *Correspondence Author Email: bonipose@yahoo.com; boniface.edegbai@uniben.edu: +234-805-914-4954
}

\begin{abstract}
The effect of treatment with cadmium and lead (mixed in a 1:1 ratio) on the growth and development of Vernonia amygdalina Del. was investigated. The plant was grown from uniform green cuttings in buckets (each with $5 \mathrm{~kg}$ dry soil) and allowed to stabilize for a month before being treated with the mixture of metals. The experiment was made up of control and four concentrations $(25,50,75$ and $100 \mathrm{mg} / \mathrm{kg})$ of the metals in each mixture. Data were collected monthly for 12 months. Result on plant height, number of leaves, and number of branches and girth of stem revealed an adverse effect of treatment at the end of the experiment except leaf area which was enhanced. Values for number of leaves $35.67 \pm 7.53,14.00 \pm 4.35,12.33 \pm 0.88,0.00$ and 0.00 were recorded for control, the $25,50,75$ and the $100 \mathrm{mg} / \mathrm{kg}$ treatments respectively,. There was decreased soil pH, microbial load and nutrients but an increase in soil carbon. The effect increased along the concentration gradient. There was more uptake of lead than cadmium.
\end{abstract}

DOI: $\underline{\text { https://dx.doi.org/10.4314/jasem.v23i5.10 }}$

Copyright: Copyright $\odot 2019$ Edegbai and Anoliefo. This is an open access article distributed under the Creative Commons Attribution License (CCL), which permits unrestricted use, distribution, and reproduction in any medium, provided the original work is properly cited.

Dates: Received: 06 March 2019; Revised: 20 May 2019; Accepted 23 May 2019

Keywords: Treatment, growth, nutrient, cadmium, lead, Vernonia amygdalina

Heavy metals are of great environmental concern due to their toxicity and cumulative behaviour (Yusuf et al., 2002). Pollution of environment by toxic metal arises as a result of various industrial activities and has turned these metal ions into subjects of major health concern (Waisberg et al., 2003). Heavy metals have become problematic in agricultural soils and crops as they are elements and as such they do not break down but rather persist in the environment endlessly (Jarup, 2003). Plants accumulate many metals and nutrients from the soil (Kachenko and Singh, 2006). As concentration of metals in soils increase, their uptake into plants also increases (Muchuweti et al., 2006). Cadmium and lead are non-essential metals and they are often found in relatively large amounts in agricultural soils. The main sources of these metals are mining, industrial processes, atmospheric deposition, fertilizers and pesticides application (Zaltauskalte et al., 2017). Of all toxic heavy metals, cadmium ranks the highest in terms of damage to plant growth and human health. Moreover, its uptake and accumulation in plants poses a serious health threat to humans via the food chain (Shah and Dubey, 1998). Lead is one of the most abundant toxic metals in the earth crust. Elevated lead in soils may compromise soil productivity and even at very low concentration can inhibit some vital plant processes. Vernonia amygdalina is a highly appreciated vegetable in West and Central Africa and can be consumed in various dishes. In Nigeria, various ethnic groups boil the leaves in soups. Dry stems and branches provide fuel. Young twigs are used as toothpicks or chewing sticks. The plant is sometimes grown as a hedge. The branches are used as stakes to line fields. (Stevels, 1990; Mbinglo, 1998; Biholong, 1986) Vernonia amygdalina is also commonly used in traditional medicine. It is this versatility that has influenced its choice for this study. Heavy metal pollution is a multielement problem in many areas (An et al., 2004). Under these circumstances, synergistic and antagonistic interactions may be important, and predicted impact based on individual effects is likely to be erroneous (Ting et al., 1991). There is therefore a clear need to understand the interactive effects produced by combinations of metal ions at different concentrations. The present study is aimed at determining the effect of the mixture of cadmium and lead on the growth and development of Vernonia amygdalina.

\section{MATERIALS AND METHOD}

Study Area: The study was carried out in the experiment plot of the Department of Plant Biology and Biotechnology, University of Benin, Edo State, Nigeria which lies within the humid Tropical 
vegetation (latitude $6^{\circ} 30^{\prime} 0^{\prime \prime} \mathrm{N}$ and longitude $6^{\circ} 0^{\prime} 0^{\prime \prime}$ E).

Collection of Plant Materials and Soil Samples:

Stem: Stem cuttings of $V$. amygdalina used in the study were obtained from a hedge composed primarily of the plant within the Senior Staff Quarters of the University of Benin, Benin City, Edo State. The soils within the location had never been polluted with any known contaminant.

Soil: Soil samples were collected from the old Botanic Garden of the Department of Plant Biology and Biotechnology, University of Benin, Edo State - a site which had remained undisturbed for over fifteen (15) years. Top soil $(0-10 \mathrm{~cm})$, of known physicochemical property was collected and dried. Thereafter, $5 \mathrm{~kg}$ soil each was placed into 15 pieces of bottom - perforated 8 litres buckets.

Preparation of Stems: Uniform $(30 \mathrm{~cm}$ long, similar girth with 3-4 buds), young and freshly collected stem cuttings of $V$. amygdalina in preparation for planting were kept partially submerged in water for about one hour before planting. Three stems were subsequently planted in each bucket.

Preparation of site: The site used for the experimental layout was properly weeded and the surface covered with black cellophane to confine the roots to the soil within the buckets.

The buckets earlier perforated and properly identified were laid out on the prepared site in a completely randomized design. Three stem cuttings of $V$. amygdalina were sown in each bucket containing $5 \mathrm{~kg}$ soil and later thinned down to one (01) after fourteen (14) days of sprouting. The stands were allowed to stabilize for one (01) month before being exposed to treatment with cadmium and lead mixture. There were 4 concentrations $(25,50,75$ and $100 \mathrm{mg} / \mathrm{kg})$ in 3 replicates and control. Cadmium and lead were measured and dissolved in distilled water and dispensed. After the soil treatment, data were collected on a monthly basis for 12 months (MAT - Months after Treatment). Soil and plant analyses were done at the end of 12 month period.

\section{Field Data Collection:}

Plant height: For plant height measurements, previously identified plant stands were tagged and growth monitored to ensure progressive evaluation and uniformity.
Number of leaves: The total number of leaves of $V$. amygdalina was taken by visual counting of the leaves on the plants.

Leaf area: Leaf area measurements of the study plants were obtained from the previously tagged plants or their branches and determinations done using the proportional method according to (Eze, 1965).

Number of branches: The number of branches for $V$. amygdalina was taken by visual counting of branches on the tagged plants at given intervals.

Girth: Girth of V. amygdalina was taken monthly. The diameter of the shoot was obtained using the Esal vernier caliper. $($ Girth $=\pi \mathrm{d})$.

Soil Physicochemical Analyses: The analyses were carried out following the methods outlined by Edegbai and Anoliefo, (2016a \&b) Soils were dried at ambient temperature $\left(22-25^{\circ} \mathrm{C}\right)$, crushed in a porcelain mortar and sieved through a $2 \mathrm{~mm}$ (10 meshes) stainless sieve, air-dried and less than $2 \mathrm{~mm}$ samples were stored in polythene bags for subsequent analysis. The fraction was used for the determination of selected soil physicochemical properties and the heavy metal fractions.

pH and Electrical Conductivity: $20 \mathrm{~g}$ of fine soil was placed in a container and $50 \mathrm{ml}$ of distilled water added. The suspension was shaken for 30minutes and allowed to settle. Electrical conductivity and $\mathrm{pH}$ of the solution were measured using a pH meter (Model 215) and conductivity meter. The $\mathrm{pH}$ meter was first standardized using a buffer solution.

Nitrogen: One gram of the soil sample was placed into a Kjedahl digestion flask. One table spoon of a catalyst and $20 \mathrm{ml}$ concentrated tetraoxosulphate (VI) acid was added and the mixture was shaken to ensure mixing. At completion of digestion, $10 \mathrm{ml}$ distilled water was added and the solution was filtered through a Whatman filter paper. Nitrogen was determined calorimetrically at $625 \mathrm{~nm}$.

Organic Carbon: One gram of the soil sample was placed in a $250 \mathrm{ml}$ conical flask. Then $10 \mathrm{ml}$ of $\mathrm{K}_{2} \mathrm{Cr}_{2} \mathrm{O}_{7}$ and $20 \mathrm{ml}$ concentrated $\mathrm{H}_{2} \mathrm{SO}_{4}$ were added and the mixture was hand shaken for minutes. Distilled water was then added to make the volume up to $150 \mathrm{ml} .10 \mathrm{ml}$ of phosphoric acid and 8 drops of diphenylamine solution were then added. A blank determination was done using $10 \mathrm{ml} \mathrm{K}_{2} \mathrm{Cr}_{2} \mathrm{O}_{7}$ and $20 \mathrm{ml}$ concentrated $\mathrm{H}_{2} \mathrm{SO}_{4}$ solution and titrated to a green colour with ferrous ammonium sulphate solution. 
The total organic carbon (TOC) was calculated as:

$$
\% \text { TOC }=\frac{T_{B}-T_{S}}{W_{S}} \times 0.3 x M 1.33
$$

$\mathrm{T}_{\mathrm{B}}=$ Titre value of blank; $\mathrm{T}_{\mathrm{S}}=$ titre value of sample, $\mathrm{W}_{\mathrm{S}}=$ Weight of sample

Available Phosphorus: One (01)g of soil was shaken for 5 minutes with $10 \mathrm{ml}$ of extracting solution containing $0.03 \mathrm{~N} \mathrm{NH}_{4} \mathrm{~F}$ and $0.1 \mathrm{~N} \mathrm{HCl}$. The solution was filtered through Whatman filter paper and $3 \mathrm{ml}$ of the filtrate was transferred into a test tube and $3 \mathrm{ml}$ of ammonium molybdate was added. Thereafter, five (05) drops of a mixture of boric acid, sodium sulphite and sodium sulphate were added. The phosphorus content was determined calorimetrically at $645 \mathrm{~nm}$.

Cation Exchange Capacity: Five (05)g of soil were placed into sterile conical flask and $20 \mathrm{ml}$ of extracting solution $\left(\mathrm{NH}_{4} \mathrm{OAc}\right)$ was added into the $250 \mathrm{ml}$ volumetric flask containing the soil samples. Whatman filter paper was then used to filter the solution. Also $0.1 \mathrm{ml}$ of the filtrate was transferred to a test tube and diluted with $10 \mathrm{ml} 0.015 \%$ strontium chloride solution. The sample was analyzed for sodium $(\mathrm{Na})$ and potassium $(\mathrm{K})$ by flame emission and for $\mathrm{Ca}$ and $\mathrm{Mg}$ by Atomic Absorption Spectrophotometry (AAS).

Sample Preparation for Analysis of Metals: Both plant and soil samples were ground into fine powder. Two (02) $\mathrm{g}$ portions of the samples were weighed accurately and $10 \mathrm{ml}$ concentrated $\mathrm{HNO}_{3}$ was added to each. The samples were digested on a hot plate for 15 minutes. The digest was cooled and $5 \mathrm{ml}$ of concentrated nitric acid was added and heated for additional 30 minutes. The latter step was repeated and the solution was reduced to about $5 \mathrm{ml}$ without boiling. The sample was cooled again and $5 \mathrm{ml}$ of concentrated hydrochloric acid and $10 \mathrm{ml}$ of distilled water was added and the sample was heated for additional 15 minutes without boiling. The sample was cooled and filtered through a Whatman No. 42 ash less filter paper and diluted to $60 \mathrm{ml}$ with distilled water. Cadmium and lead contents in the digested samples were analyzed for using the Atomic Absorption Spectrophotometer.

Statistics: Statistical analysis was carried out by determining the mean and standard error of three replicates.

\section{RESULTS AND DISCUSSION}

Plant height for $V$. amygdalina grown in soil treated with various levels of $\mathrm{Cd}+\mathrm{Pb}$ and control is presented in Figure 1. Values recorded show that at the end of the experiment, control had the highest value while the
$25 \mathrm{mg} / \mathrm{kg}$ and $50 \mathrm{mg} / \mathrm{kg}$ had significantly $(\mathrm{P}<0.05)$ lower values. At the same time, the $75 \mathrm{mg} / \mathrm{kg}$ and 100 $\mathrm{mg} / \mathrm{kg}$ treated soils had lost all their plants. The values $77.43 \pm 1.45,62.37 \pm 2.04,59.23 \pm 3.96,0.00$ and 0.00 $\mathrm{cm}$ were recorded for control, the 25, 50, 75 and 100 $\mathrm{mg} / \mathrm{kg}$ treatments respectively at the end of the experiment.

The effect of $\mathrm{Cd}+\mathrm{Pb}$ treatment on the number of leaves of $V$. amygdalina is shown in Figure 2. The results show that the control plants recorded higher number of leaves compared to the treatments. At 12 MAT, control plants recorded significantly higher ( $\mathrm{P}$ $<0.05)$ number of leaves while the treatments showed adverse effect along the concentration gradient. The values $35.67 \pm 7.53,14.00 \pm 4.35,12.33 \pm 0.88,0.00$ and 0.00 represent results for number of leaves for control, the $25,50,75$ and $100 \mathrm{mg} / \mathrm{kg}$ treatments respectively, at the end of the experiment.

Growth as seen in plant height (Figure 1) and number of leaves (Figure 2) revealed a significant adverse effect of treatment compared to control. Higher concentrations of treatment $(75 \mathrm{mg} / \mathrm{kg}$ and $100 \mathrm{mg} / \mathrm{kg}$ ) resulted in the death of plants. When $V$. amygdalina was treated with cadmium alone (Edegbai and Anoliefo, 2016a) growth inhibition and death of plants also occurred. In that experiment, control plant height was $77.43 \pm 1.45 \mathrm{~cm}$ while the $25,50,75$ and $100 \mathrm{mg} /$ $\mathrm{kg}$ had heights of $39.77 \pm 2.32 \mathrm{~cm}, 28.77 \pm 4.32 \mathrm{~cm}$, $0.00 \mathrm{~cm}$ and $0.00 \mathrm{~cm}$ respectively. However, when treated with lead alone, all plant stands survived through the period of the experiment with height values of $77.43 \pm 1.45,72.47 \pm 7.33,57.27 \pm 5.71,68.67$ \pm 6.13 and $66.47 \pm 5.60 \mathrm{~cm}$ for control and the 25,50 , 75 and $100 \mathrm{mg} / \mathrm{kg}$ treatments. (Edegbai and Anoliefo, $2016 \mathrm{~b})$. The severity of adverse effect of these treatments compared to the current treatment is in the order $\mathrm{Cd}>\mathrm{CdPb}>\mathrm{Pb}$. It is apparent that both heavy metals were antagonistic to each other.

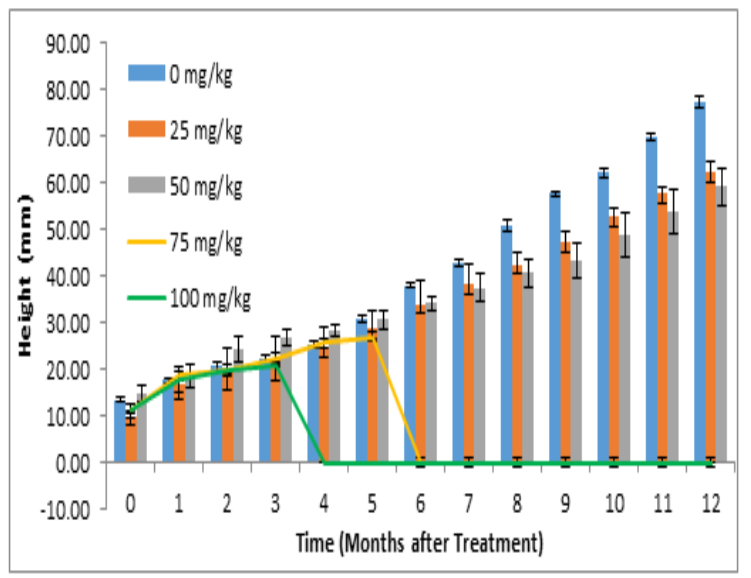

Fig 1: Effect of $\mathrm{Cd}+\mathrm{Pb}$ mixture on the height $(\mathrm{cm})$ of $V$. amygdalina 


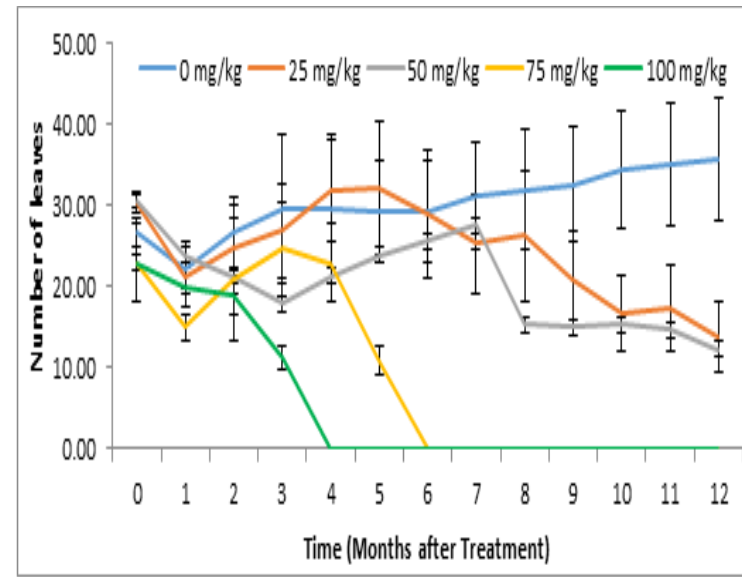

Fig 2: Effect of $\mathrm{Cd}+\mathrm{Pb}$ mixture on the number of leaves of $V$. amygdalina

Mean leaf area results of $V$. amygdalina for control and cadmium and lead mixtures treated soil are shown in Figure 3. Control values were consistently lower than the values recorded for the $25 \mathrm{mg} / \mathrm{kg}$ and $50 \mathrm{mg} / \mathrm{kg}$ treatments while the $75 \mathrm{mg} / \mathrm{kg}$ and $100 \mathrm{mg} / \mathrm{kg}$ treatment had lost all plant stands at 6 MAT and 4 MAT respectively. The values - $17.45 \pm 4.84$, $37.29 \pm 8.55,23.4 \pm 8.46,0.00$ and $0.00 \mathrm{~cm}^{2}$ are leaf area values taken at the termination of the experiment for control, the $25,50,75$ and $100 \mathrm{mg} / \mathrm{kg}$ treatments respectively.

Figure 4 shows the effect of $\mathrm{Cd}+\mathrm{Pb}$ mixture on the number of branches of $V$. amygdalina from 0 MAT to 12 MAT. There was a consistent increase in control values until 10 MAT. There was however a decrease in values recorded for the $25 \mathrm{mg} / \mathrm{kg}$ treatment at 6 MAT while $75 \mathrm{mg} / \mathrm{kg}$ and $100 \mathrm{mg} / \mathrm{kg}$ lost all branches at 6 MAT and 4 MAT respectively. There was no significant difference $(\mathrm{P}<0.05)$ in the mean value for control $(4.67 \pm 0.66)$, the $25 \mathrm{mg} / \mathrm{kg}(4.00 \pm 0.00)$ and the $50 \mathrm{mg} / \mathrm{kg}(3.33 \pm 1.33)$ treatments.

Figure 5 shows the effect of $\mathrm{Cd}+\mathrm{Pb}$ mixture on the girth $(\mathrm{mm})$ of $V$. amygdalina. All the treatments recorded increases in girth from 0 MAT to 12 MAT except the $75 \mathrm{mg} / \mathrm{kg}$ and $100 \mathrm{mg} / \mathrm{kg}$ treatments which lost all plants by 6 MAT and 4 MAT respectively. There was no significant difference $(\mathrm{P}<0.05)$ between control, the $25 \mathrm{mg} / \mathrm{kg}$ and the $50 \mathrm{mg} / \mathrm{kg}$, though these were significantly different from the $75 \mathrm{mg} / \mathrm{kg}$ and 100 $\mathrm{mg} / \mathrm{kg}$ treatments. The values $-71 \pm 0.00,15.71 \pm 1.81$, $16.76 \pm 1.04,0.00$ and $0.00 \mathrm{~mm}$ were girth values recorded for control, the $25,50,75$ and $100 \mathrm{mg} / \mathrm{kg}$ treatments respectively at the end of the experiment.

Results on leaf area (Figure 3) revealed that treatment favoured the leaf area as control recorded lower values. In an earlier report, Cadmium alone resulted in decreased value for leaf area in treated plants while lead alone did not record any significant difference between control and treated plants (Edegbai and Anoliefo, 2016a \&b). The mixture revealed less adverse effect as compared to the individual metals with the $25 \mathrm{mg} / \mathrm{kg}$ and the $50 \mathrm{mg} / \mathrm{kg}$ (Figure 3) treatments. Treatment had no significant adverse effect on number of branches (Figure 4) and girth (Figure 5) of stem at lower concentrations.

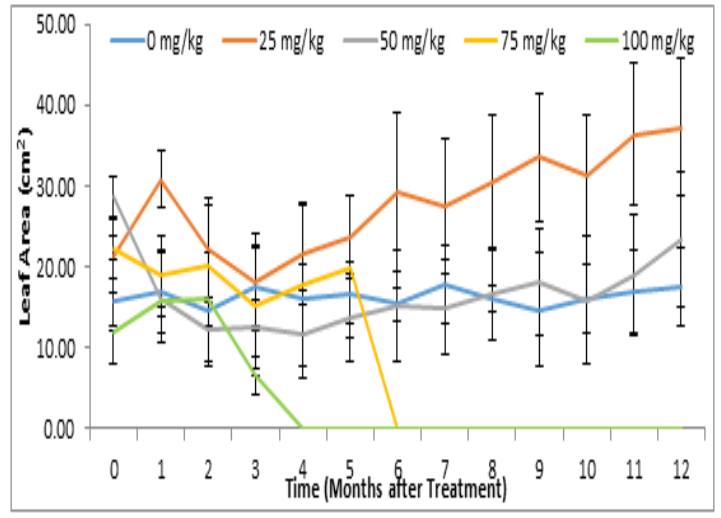

Fig 3: Effect of $\mathrm{Cd}+\mathrm{Pb}$ mixture on the leaf area $\left(\mathrm{cm}^{2}\right)$ of $V$. amygdalina

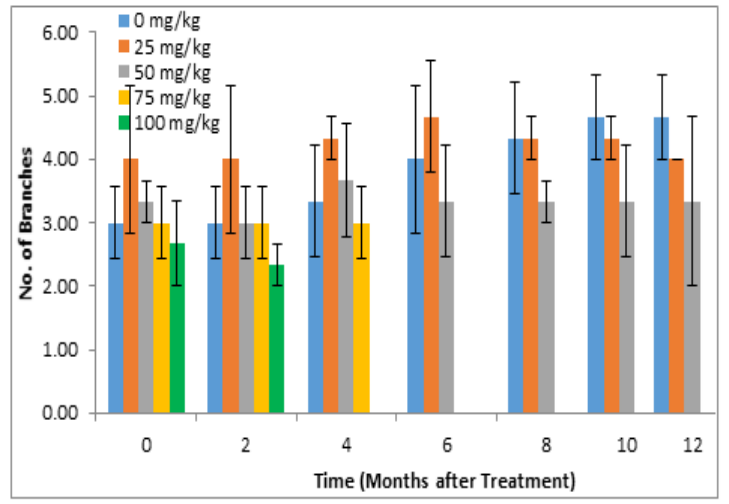

Fig 4: Effect of $\mathrm{Cd}+\mathrm{Pb}$ mixture on the number of branches of $V$. amygdalina

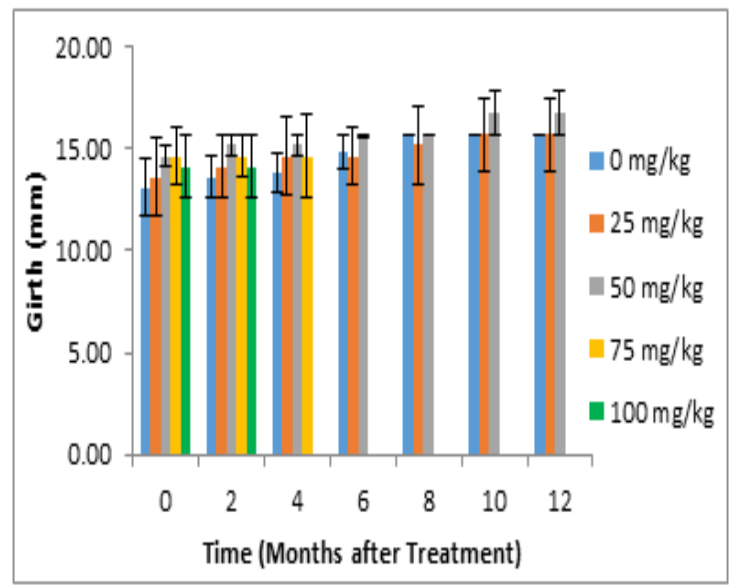

Fig 5: Effect of $\mathrm{Cd}+\mathrm{Pb}$ mixture on the girth $(\mathrm{mm})$ of $V$. amygdalina 
Table 1 shows the results of $\mathrm{pH}$ and chemical analyses for soil at the end of the experiment. The $\mathrm{pH}$ was depressed by the presence of cadmium and lead and the effect was along the concentration gradient. The treatment also depressed the nutrient elements $(\mathrm{N}, \mathrm{Ph}$, $\mathrm{Ca}$ and $\mathrm{Mg}$ ) composition of the soil. Conversely however, the carbon content of the soil increased as the cadmium and lead treatment concentration increased.

Result on soil pH (Table 1) revealed an increase in acidity along the concentration gradient. The mobility and availability of heavy metals and soil nutrients is greatly determined by soil $\mathrm{pH}$. Increased acidity results in increase in the heavy metals available in solution in the soil and consequently to the plants. Depending on the reaction of the plant species to the presence of the heavy metals, they could exhibit effects commensurate with the degree of exposure. Sauve et al. (1997), Nolan et al. (2003) and Su et al. (2007) reported that the solubility of heavy metals was significantly related to their total concentration, together with soil $\mathrm{pH}$. The increased acidity along the concentration gradient is similar to results obtained by Edegbai and Anoliefo (2016a \&b) when they treated $V$. amygdalina with cadmium and lead separately.

The carbon constituent (Table 1) increased along the concentration gradient. Similarly, individual cadmium and lead treatment resulted in an increase in carbon constituent. Zhang and Wang (2007) revealed that high amount of heavy metals in polluted soil could slow down the mineralization rate of soil organic $\mathrm{C}$ and increase the amount of hardly biodegradable $\mathrm{C}$.

The results on other analyses show that $\% \mathrm{~N}, \% \mathrm{P}, \% \mathrm{Ca}$ and $\% \mathrm{Mg}$ (Table 1) decreased with an increase in the concentration of treatment. Wu et al. (2007) discovered that the presence of $\mathrm{Cd}$ and $\mathrm{Pb}$ reduced the plant uptake rate of essential elements like Mn, Fe, K, $\mathrm{Mg}$ and $\mathrm{Ca}$. Plants cultivated in soil contaminated with heavy metals are subject to modification of the chemical composition of not only the content of heavy metals but also macronutrients (Ciecko et al., 2004).

Table 1: Physicochemical properties of $\mathrm{Cd}+\mathrm{Pb}$ post $V$. amygdalina cultivated soil at the end of the experiment (12 MAT)

\begin{tabular}{lllllllll}
\hline $\begin{array}{l}\text { Concentration } \\
\mathrm{mg} / \mathrm{kg}\end{array}$ & $\mathrm{pH}$ & $\begin{array}{l}\text { Carbon } \\
(\%)\end{array}$ & $\begin{array}{l}\text { Nitrogen } \\
(\%)\end{array}$ & $\begin{array}{l}\text { Phosphorus } \\
(\%)\end{array}$ & $\begin{array}{l}\mathrm{Ca} \\
(\mathrm{ppm})\end{array}$ & $\begin{array}{l}\mathrm{Mg} \\
(\mathrm{ppm})\end{array}$ & $\begin{array}{l}\mathrm{K} \\
(\mathrm{ppm})\end{array}$ & $\begin{array}{l}\mathrm{Na} \\
(\mathrm{ppm})\end{array}$ \\
\hline 0 & 8.1 & 0.82 & 0.29 & 3.71 & 1.26 & 0.82 & 0.21 & 0.11 \\
25 & 5.9 & 1.12 & 0.18 & 2.80 & 0.88 & 0.70 & 0.11 & 0.05 \\
50 & 5.6 & 1.17 & 0.13 & 2.52 & 0.81 & 0.63 & 0.08 & 0.03 \\
75 & 5.4 & 1.26 & 0.11 & 2.27 & 0.73 & 0.46 & 0.06 & 0.02 \\
100 & 5.1 & 1.34 & 0.09 & 2.01 & 0.65 & 0.34 & 0.05 & 0.01 \\
\hline
\end{tabular}

Table 2 shows the concentration of cadmium and lead accumulated by the plant at the end of the experiment. The amount of both metals accumulated by the plant increased with increase in the concentration of their treatment. The metals were not detected in the control plants. The highest uptake of $0.138 \mathrm{ppm}$ and $0.387 \mathrm{ppm}$ were recorded for $100 \mathrm{mg} / \mathrm{kg}$ treatment with $\mathrm{Cd}$ and $\mathrm{Pb}$. When treated with cd alone (Edegbai and Anoliefo, 2016a) and pb alone (Edegbai and Anoliefo, 2016b) uptake values of $0.283 \mathrm{ppm}$ and $0.871 \mathrm{ppm}$ were recorded for the $100 \mathrm{mg} / \mathrm{kg}$ treatment. It presents an antagonistic relationship between the metals. Presence of one hindered the uptake of the other. Similar results were obtained by Alia et al (2015). Results of microbial analyses (Table 3) showed reduction in the quantity of bacteria and fungi in the soil. The effect increased as the concentration of treatment increased. Similar results were obtained with individual treatments of cadmium and lead. Wyskowska et al. (2008) revealed that heavy metals resulted in a decrease in microbial biomass and a reduction in their activity in the soil. In cases when they do not lower counts of microorganisms, they still reduce their diversity (Xie et al., 2009; Wakelin et al., 2010).
Table 2: Composition of heavy metals in $V$. amygdalina cultivated soil at the end of the experiment (12 MAT)

\begin{tabular}{lll}
\hline Concentration $\mathrm{mg} / \mathrm{kg}$ & $\mathrm{Cd}(\mathrm{ppm})$ & $\mathrm{Pb}(\mathrm{ppm})$ \\
\hline 0 & $\mathrm{ND}$ & $\mathrm{ND}$ \\
25 & 0.045 & 0.097 \\
50 & 0.053 & 0.177 \\
75 & 0.087 & 0.209 \\
100 & 0.138 & 0.387 \\
\hline \multicolumn{3}{l}{}
\end{tabular}

Table 3 Results of microbial analyses

\begin{tabular}{lll}
\hline $\begin{array}{l}\text { Concentration } \\
\mathrm{mg} / \mathrm{kg}\end{array}$ & $\begin{array}{l}\text { Bacterial } \\
(\mathrm{cfu} / \mathrm{g})\end{array}$ & $\begin{array}{l}\text { Fungal } \\
(\mathrm{cfu} / \mathrm{g})\end{array}$ \\
\hline 0 & $1.37 \times 10^{5}$ & $6.7 \times 10^{4}$ \\
25 & $7.3 \times 10^{4}$ & $2.7 \times 10^{4}$ \\
50 & $6.3 \times 10^{4}$ & $2.6 \times 10^{4}$ \\
75 & $5.5 \times 10^{4}$ & $2.4 \times 10^{4}$ \\
100 & $4.8 \times 10^{4}$ & $2.0 \times 10^{4}$ \\
\hline
\end{tabular}

Conclusion: In this study, the impact of mixture of the $\mathrm{Cd}$ and $\mathrm{Pb}$ on the growth and development of $V$. amygdalina was investigated. The interaction between the heavy metals, though antagonistic, resulted in inhibition of growth of $V$. amygdalina. Uptake of the metals was reduced as a result of this competitive interaction. 


\section{REFERENCES}

Alia, N; Sadar, K; Said, M; Salma, K; Sadia, A; Sadaf, S; Toqeer, A; Miklas, S (2015). Toxicity and bioaccumulation of heavy metals in spinach (Spinacia oleracea) grown in a controlled environment. Int J of Environ Res and Pub Health 12: $7400-7416$

An, YJ; Kim, YM; Kwon, TL; Jeong, SW (2004). Combined effects of copper, cadmium and lead upon Cucumis sativus growth and bioaccumulation. Sci. Total Environ. 326: 85 - 93

Biholong, M (1986). Contribution à l'étude de la flore du Cameroun. Les Asteraceae. Thèse de Doctorat d'Université de Bordeaux III, Bordeaux, France. 354 pp

Ciecko, Z; Kalembasa, S; Wyszkowski, M; Rolka, E. (2004). The effect of elevated cadmium content in soil on the uptake of nitrogen by plants. Plant, Soil, Environ. 50(7): 283 - 294

Edegbai, BO; Anoliefo, GO (2016). Growth and development of Vernonia amygdalina Del in soils treated with lead. NISEB J. 16(1): $20-26$

Edegbai, BO; Anoliefo, GO (2016). (2016). Toxicity of cadmium to Vernonia amygdalina Del. Eur. Int. J of Sci and Tech 5(4): 110 - 120

Eze, JMO (1965). Studies on growth regulation, salt uptake and translocation $\mathrm{PhD}$ Thesis, University of Durham, United Kingdom.pp 31 - 33

Jarup, L (2003). Hazards of heavy metal contamination. British Medical Bulletin 68: 167 182

Kachenko, AG; Singh, B (2006). Heavy metals contamination in vegetable grown in urban and metal smelter contaminated sites in Australia.Water, Air and Soil Pollution 169: 101 123

Mbinglo, SB (1998). Survey on the production of bitterleafVernonia spp. in Bamenda, N.W

Cameroon. Student project report for Natural Resource Institute, Chatham, United Kingdom/Dschang University Cameroon

Muchuweti, M; Birkett, JW; Chinyanga, E; Zvauya, R; Scrimshaw, MD; Lester, JN. (2006). Heavy metal content of vegetables irrigated with mixture of wastewater and sewage sludge in Zimbabwe:
Implications for human health. Agric., Ecosystems and Environ 112: 41 - 48

Nolan AL; Lombi E; Mclaughlin MJ. (2003) Metal bioaccumulation and toxicity in soils-why bother with speciation? Aust. J. chem 56:1-15

Sauve, S; McBride, MB; Norvell, WA; Hendershot, WH (1997). Copper solubility and Speciation of in situ contaminated soils: effects of copper level, pH and organic matter. Wat, Air Soil Pol. 100: 133-149

Shah, K; Dubey, RS (1998). A 18KDa cadmium inducible protein complex from rice: its purification and characterization from rice (Oryza sativa L.) roots tissues. J. Plant Physiol. 152: 448 $-454$

Stevels, JMC (1990). Légumes traditionnels du Cameroun: une étude agrobotanique.Wageningen Agricultural University Papers No 90-1. Wageningen University, Wageningen, Netherlands. 262 pp.

Su, W; Charlock, TP; Rose, FG; Rutan, D (2007). Photosynthetically active radiation from clouds and the Earth's radiant energy system (CERES) products. J. Geophy. Res. 112: 1-11

Ting, YP; Lawson, F; Prince, IG (1991). Uptake of cadmium and zinc by alga Chlorella vulgaris: Multi-ion situation. Biotech. Bioeng. 37: 445 455

Waisberg, M; Joseph, P; Hale, B; Beyersmann, D (2003).Molecular and cellular mechanisms of cadmium carcinogenesis. Toxicol. 192: 95 - 117

Wakelin, SA; Chu, G; Lardner, R; Liang, Y; McLaughlin, M. (2010). A single application of $\mathrm{Cu}$ to field soil has long term effects on bacterial community structure, diversity and soil processes. Pedobiologia 53: 149 - 158

Wu, FB; Zhang, GP; Dominy, P; Wu, HX; Bachir, DML (2007). Differences in yield components and kernel $\mathrm{Cd}$ accumulation in response to $\mathrm{Cd}$ toxicity in four barley genotypes. Chemosphere $70(1): 83-92$

Wyszkowska, J; Kucharski, J; Borowik, A; Boros, E (2008). Response of bacteria to soil contamination with heavy metals. J. Elementol. 13(3): $443-453$ 
Xie, W; Zhou, J; Wang, H; Chen, X; Lu, Z; Yu, J; (2009).Short term effect of copper, cadmium and cypermethrin on dehydrogenase activity and microbial functional diversity in soils after long term mineral or organic fertilization. Agric. Ecos. Environ. 129: 450 - 456

Yusuf, AA; Arowolo, TA; Bamgbose, O (2002). Cadmium, copper and nickel levels in vegetables from industrial and residential areas of Lagos City, Nigeria. Food and Chem. Tox. 41: 375 - 378
Zaltauskaite, J; Mikalaikeviciute, L; Sujetoviene, L; Miskelyte, D (2017). Evaluation of heavy metals binary metals mixtures toxicity on spring barley (Hordeum vulgare). $15^{\text {th }}$ International Conference on Environmental Science and Technology 4pp

Zhang, MK; Wang, LP (2007). Impact of heavy metals pollution on soil organic matter accumulation. $J$. Appl. Ecol. 18 (7): 1479 - 1483 